\title{
Flame Atomic Absorption Spectrometric Determination of Trace Amounts of Manganese in Alloys and Biological Samples after Preconcentration with the Ion Pair of 2-(5-Bromo-2- pyridylazo)-5-diethylaminophenol and Ammonium Tetraphenylborate on Microcrystalline Naphthalene or by Column Method
}

\author{
Mohammad Ali TAHER \\ Department of Chemistry, Shahid Bahonar University of Kerman, Kerman, Iran
}

\begin{abstract}
Manganese is quantitatively retained on 2-(5-bromo-2-pyridylazo)-5-diethylaminophenol (5-Br-PADAP)-ammonium tetraphenylborate with microcrystalline naphthalene or by a column method in the $\mathrm{pH}$ range $7.5-10.5$ from large volumes of aqueous solutions of various samples. After filtration, each solid mass consisting of the manganese complex and naphthalene was dissolved with $5 \mathrm{ml}$ of dimethylformamide and the metal was determined by flame atomic absorption spectrometry. Manganese complex can alternatively be quantitatively adsorbed on ammonium tetrphenylborate-naphthalene adsorbent packed in a column and determined similarly. About $0.1 \mu \mathrm{g}$ of manganese can be concentrated in a column from $500 \mathrm{ml}$ of aqueous sample, where its concentration is as low as $0.2 \mathrm{ppb}$. Eight replicate determinations of $1.0 \mathrm{ppm}$ of manganese gave a mean absorbance of 0.224 with a relative standard deviation of $1.8 \%$. The sensitivity for $1 \%$ absorption was $19 \mathrm{ppb}$. The interference of a large number of anions and cations has been studied and the optimized conditions developed were utilized for the trace determination of manganese in various standard samples.
\end{abstract}

(Received December 8, 2000; Accepted May 10, 2001)

\section{Introduction}

A large number of industries discharge metal-containing effluents into water resources without adequate treatment. Contamination of the environment by manganese is currently an area of concern. Although manganese is an essential micronutrient, over-exposure causes poisonous effects. ${ }^{1}$ Manganese compounds are known to catalyze the oxidation of sulfur dioxide to sulfur trioxide. ${ }^{2}$ Manganese is present in many alloys and is also found in a number of pharmaceutical, biological and environmental samples. Hence the rapid separation and determination of this metal is desirable.

Sodium tetraphenylborate (TPB) and its derivatives have been used in the estimation of alkali and univalent metal ions. ${ }^{3-5}$ It has also been used as a counter ion in the extraction and adsorption of some metal complexes on microcrystalline naphthalene. ${ }^{6}$ A survey of the literature reveals that metal ions may be preconcentrated on various adsorbents such as thiol cotton, ${ }^{7}$ silanized glass beads, ${ }^{8}$ silica gel, ${ }^{9}$ Amberlite XAD-4 resin, ${ }^{10}$ cellulose,${ }^{11}$ green tea leaves ${ }^{12}$ and polythioether foams. ${ }^{13}$ Some of these adsorbents may be fairly effective for preconcentration of metal ions, but their methods of preparation are lengthy and involve rigid control of conditions. The desorption of the metal is carried out by the slow process of elution (the metal complex is probably held by the interior

E-mail: taher@arg3.uk.ac.ir surfaces of the adsorbent and thus the adsorbed complex is not eluted easily), hence the procedure is time consuming. Solvent extraction is a simple and convenient technique for separating and concentrating metal ions, but it can not be applied directly to metal ions which form stable complexes with the chelating agents only at elevated temperature. This difficulty can be overcome by using naphthalene as the extractant ${ }^{14}$ for thermally stable metal chelates. ${ }^{15}$ Solid-liquid separation after adsorption of metal chelates on microcrystalline naphthalene is more rapid and convenient and can be applied to many types of metal complexes. ${ }^{16-19}$ The preconcentration of manganese ion is also possible by passing its aqueous solution over naphthalene- $\mathrm{NH}_{4-}$ TPB adsorbent taken in a column. The microcrystalline naphthalene method is rapid but the column method gives a better preconcentration factor. ${ }^{20-22}$

In this paper, a highly selective and sensitive preconcentration method has been developed; it uses 2-(5-bromo-2-pyridylazo)5-diethylaminophenol (5-Br-PADAP) as the complexing reagent and in addition to the $\left(\mathrm{NH}_{4}{ }^{+}\right)\left(\mathrm{TPB}^{-}\right)$ion pair supported on naphthalene. The 5-Br-PADAP reacts with manganese to form a water-soluble complex cation, but in the presence of the TPB anion it forms a water-insoluble complex (Mn-5-BrPADAP-TPB). Preliminary observations revealed that the Mn5-Br-PADAP complex cation could be quantitatively retained on an ammonium tetraphenylborate adsorbent supported on naphthalene. The solid mass, consisting of the metal ionassociated complex and naphthalene, can easily be dissolved with a suitable organic solvent such as dimethylformamide 
(DMF) and the manganese is then determined by atomic absorption spectrometry. The interference of a number of metal ions and anions on the estimation of manganese has been studied in detail. The developed method is found to be highly sensitive and selective and has been employed for the estimation of manganese in complex materials.

\section{Experimental}

\section{Apparatus and reagents}

A Zeiss Atom-Absorption-Spectrometer FMD 3 (Germany) was used. All absorption measurements were performed under the following operating conditions: wavelength, $280 \mathrm{~nm}$; slit setting, $0.08 \mathrm{~mm}$; current, $15 \mathrm{~mA}$; acetylene flow setting, 10 (pressure, $0.9 \mathrm{kPa} \mathrm{cm}^{-2}$ ); air flow setting, 16 (pressure, $1.2 \mathrm{kPa}$ $\mathrm{cm}^{-2}$ ). A Beckman $\mathrm{pH}$ meter was employed for $\mathrm{pH}$ measurements. A funnel-tipped glass tube $(60 \times 6 \mathrm{~mm})$ was used as a column for preconcentration. It was plugged with polypropylene fibbers and then filled with the adsorbent to a height of $1.0-1.2 \mathrm{~cm}$ after pressing slightly with a flat glass rod. All glassware and the column were washed with a mixture of concentrated sulfuric acid and concentrated nitric acid $(1+1)$ before use. All reagents were of analytical reagent grade. A standard manganese solution was prepared from manganese(II) sulfate in distilled water and standardized by known methods..$^{23}$ A $0.01 \%$ solution of 5-Br-PADAP in ethanol was prepared. Buffer solutions of $\mathrm{pH} 3-6,6-8$ and $8-11$ were prepared by mixing appropriate ratios of a $0.5 \mathrm{M}$ acetic acid and $0.5 \mathrm{M}$ sodium acetate solution, $0.1 \mathrm{M}$ sodium dihydrogenphosphate solution and $0.1 \mathrm{M}$ dipotassium hydrogenphosphate solution, and $0.5 \mathrm{M}$ ammonia solution and $0.5 \mathrm{M}$ ammonium acetate solution, respectively. A $1 \%$ solution sodium tetraphenylborate (TPB) was prepared in distilled water. A $20 \%$ solution of naphthalene was prepared in acetone. Solutions of alkali metal salts $(1 \%)$ and various metal salts $(0.1 \%)$ were used for studying the interference of anions and cations, respectively.

\section{Preparation of naphthalene- $\mathrm{NH}_{4}-\mathrm{TPB}$ adsorbent}

A solution of naphthalene was prepared by dissolving $20 \mathrm{~g}$ of naphthalene in $40 \mathrm{ml}$ of acetone on a hot-plate stirrer at 30 $35^{\circ} \mathrm{C}$. This solution was transferred into $1500 \mathrm{ml}$ of distilled water containing $25 \mathrm{ml}$ of $1 \mathrm{~mol}^{-1}$ ammonium acetate and 75 $\mathrm{ml}$ of $1 \mathrm{~mol}^{-1}$ ammonia solution ( $\mathrm{pH} 9.5$ ), in a fast stream continuous flow with continuous stirring at room temperature. Then, to this solution, $500 \mathrm{ml}$ of an aqueous solution containing $1.7 \mathrm{~g}$ of TPB was added. The naphthalene coprecipitated with $\mathrm{NH}_{4}{ }^{+}$and $\mathrm{TPB}^{-}$. The solution was stirred for about $2 \mathrm{~h}$ and then allowed to stand for $2 \mathrm{~h}$. The supernatant solution was decanted off and the remaining solid mass was washed twice with distilled water. The adsorbent in the form of a slurry was stored in a bottle for subsequent use.

\section{General procedure for the column method}

An aliquot of the solution (up to $500 \mathrm{ml}$ ) containing $0.1-15$ $\mu \mathrm{g}$ of manganese was taken in a beaker and $2.0 \mathrm{ml}$ of $0.01 \%$ alcoholic solution of 5-Br-PADAP and $2.0 \mathrm{ml}$ of acetate buffer of $\mathrm{pH} \sim 9$ were added to it. The column loaded with the adsorbent $\mathrm{NH}_{4}$-TPB-naphthalene was conditioned to $\mathrm{pH} \sim 9$ by passing $2-5 \mathrm{ml}$ of the acetate buffer solution at a flow rate of 1

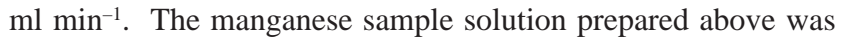
then passed at a flow rate of $1 \mathrm{ml} \mathrm{min}$. The packing in the column was washed with a few milliliters of distilled water and then aspirated strongly for $2-3 \mathrm{~min}$, pushing down the solid mass in the column with a glass rod in order to eliminate the excess water attached to the adsorbent. The metal complex was dissolved out of the column along with naphthalene with $5 \mathrm{ml}$ of DMF. The solution was aspirated into an air-acetylene flame and the absorbance was measured at $280 \mathrm{~nm}$ against a reagent blank. The absorbances for standard amounts of manganese were measured and a calibration curve was constructed against a reagent blank prepared in a similar manner.

\section{General procedure for microcrystalline naphthalene}

An aliquot of manganese solution (up to $200 \mathrm{ml}$ containing $0.1-15 \mu \mathrm{g}$ ) was placed in an Erlenmeyer flask with a tightly fitting stopper. Then a $2-\mathrm{ml}$ volume of $0.01 \%$ of the reagent (5Br-PADAP) was added to it. The $\mathrm{pH}$ was adjusted to $\sim 9$ with 2 $\mathrm{ml}$ of the buffer, and then $2 \mathrm{ml}$ of $1 \%$ TPB solution was added. The solution was mixed well and allowed to stand for a few seconds. Then $2 \mathrm{ml}$ of a $20 \%$ solution of naphthalene in acetone was added to it with continuous shaking. The solid mass so formed consisting of naphthalene and metal complex was separated by filtration on a Whatman filter paper (No. 1041). The residue was dried in the folds of a filter paper and transferred to the Erlenmeyer flask. The solid mass consisting of the metal complex along with naphthalene was dissolved with $5 \mathrm{ml}$ of dimethylformamide (DMF). The solution was aspirated into an air-acetylene flame and the absorbance was measured at $280 \mathrm{~nm}$ against a reagent blank solution prepared in the same way. A calibration graph was prepared by taking various known amounts of manganese under the conditions given above.

\section{Results and Discussion}

\section{Retention characteristics of $\mathrm{NH}_{4}-\mathrm{TPB}$}

Sodium tetraphenylborate $\left(\mathrm{TPB}^{-}\right)$is soluble in water, it forms water-insoluble precipitates with some alkali metal ions such as $\mathrm{K}^{+}, \mathrm{Rb}^{+}, \mathrm{Cs}^{+}$(but not $\mathrm{Li}^{+}, \mathrm{Na}^{+}$), and univalent metal ions such as $\mathrm{Ag}^{+}, \mathrm{Tl}^{+}$, and $\mathrm{Cu}^{+}$, but does not form precipitates with multivalent metal ions. It has been used as a gravimetric and volumetric reagent. Furthermore, it also reacts with ammonium salts such as $\mathrm{NH}_{4}{ }^{+}$and its derivatives to form water-insoluble precipitates. The $\mathrm{TPB}^{-}$forms a weakly bonded ion-pair with $\mathrm{NH}_{4}{ }^{+}$in aqueous solution and coprecipitates with microcrystalline naphthalene as follows:

$$
\mathrm{NH}_{4}{ }^{+}+\mathrm{TPB}^{-} \rightleftharpoons\left(\mathrm{NH}_{4}{ }^{+}\right)\left(\mathrm{TPB}^{-}\right)(\mathrm{s})
$$

From the experimental observation, the $\mathrm{NH}_{4}-\mathrm{TPB}$ ion-pair, produced from $\mathrm{TPB}^{-}$and ammonium acetate in aqueous solution, was unstable when supported on naphthalene and partly desorbed from the surface of the naphthalene in the column on passage of the buffer of $\mathrm{pH} \sim 9$. However, the $\mathrm{NH}_{4}$ TPB ion-pair prepared in acetate buffer of $\mathrm{pH} 9.5$ is highly stable and $\mathrm{TPB}^{-}$is not desorbed even on washing with water or the buffer of $\mathrm{pH} \sim 9$. The adsorbent shows excellent absorption characteristics for various cationic metal complexes, such as $\mathrm{Fe}(1,10-\mathrm{Phen})_{3}{ }^{2+}$. In this work, $\mathrm{TPB}^{-}$has been selected as the counter-ion because of its purity and moderate price.

\section{Reaction conditions}

These were established with the use of $5 \mu \mathrm{g}$ of manganese. The adsorption of manganese on this adsorbent was found to be a maximum in the $\mathrm{pH}$ range 7.5 - 10.5. In subsequent studies, the $\mathrm{pH}$ was maintained at approximately 9. Addition of $0.5-5$ $\mathrm{ml}$ of the buffer did not affect the retention of manganese and the use of $2 \mathrm{ml}$ is recommended. Various amounts of $0.01 \%$ 
alcoholic solution of 5-Br-PADAP were tried. Manganese was quantitatively adsorbed on the adsorbent over the range $1.0-3.0$ $\mathrm{ml}$ of the reagent. Therefore, a $2.0-\mathrm{ml}$ volume of the reagent is recommended in the present study.

Various amounts of naphthalene (20\% solution of naphthalene in acetone) were added to the sample solutions keeping other variables constant. It was observed that the signal height remained constant with the addition of $1.0-4.0 \mathrm{ml}$ of $20 \%$ naphthalene solution. Therefore, a $2.0-\mathrm{ml}$ volume of $20 \%$ naphthalene solution was used in subsequent studies. The effect of shaking time on the adsorption indicated that the signal height remained constant over a range of $0.5-5.0 \mathrm{~min}$. Therefore, $1.0 \mathrm{~min}$ of shaking time was maintained in the present work.

In the case of the column method, the flow rate was varied from 0.2 to $8 \mathrm{ml} / \mathrm{min}$. It was found that a flow rate of $0.2-5.0$

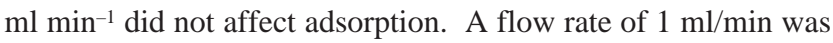
recommended in all experiments.

The volume of the aqueous phase was varied in the range of $10-700 \mathrm{ml}$ under the optimum conditions, keeping the other variables constant. It was observed that the signal height was almost constant up to $200 \mathrm{ml}$ (preconcentration factor of 40). However, for convenience, all the experiments were carried out with $40 \mathrm{ml}$ of the aqueous phase. Whereas, in the case of column method, signal height was almost constant up to an aqueous phase volume of $500 \mathrm{ml}$. Therefore, a preconcentration factor of 100 can be achieved by the column.

\section{Choice of solvent}

A number of solvents were tried, to dissolve the metal complex along with naphthalene. Since the solid mass is dissolved in a small volume $(3-5 \mathrm{ml})$ of solvent, it is essential to select a solvent in which the chelate is highly soluble and one which is also sensitive for atomic absorption spectrometric measurements. The solid material is insoluble in ordinary organic solvents such as toluene, 1,2-dichloroethane, hexane, nitrobenzene, isoamyl alcohol, 1-amyl alcohol, ethyl acetate, methyl isobutyl ketone, chloroform and dioxane, but is soluble in dimethyl sulfoxide, DMF, and propylene carbonate. DMF was preferred because of the high solubility and stability of metal complex on naphthalene. It was found that $2-3 \mathrm{ml}$ of this solvent was sufficient to dissolve the entire mixture, thus further enhancing the sensitivity of the method. Since only a small volume $(3-5 \mathrm{ml})$ of the solvent is required to dissolve the solid mass, it was essential to study the effect of the surplus water attached to the absorbent. It was found that the surplus water caused the absorbance to decrease by $10-12 \%$ and this led to an error in the determination. Thus, it was necessary to eliminate the water attached to naphthalene in the column completely by aspirating the column for $2-3 \mathrm{~min}$.

\section{Retention capacity of the adsorbent}

The retention capacity of adsorbent was determined by a batch method. The experiment was performed by adding $500 \mu \mathrm{g}$ of manganese, $2 \mathrm{ml}$ of the buffer ( $\mathrm{pH} \sim 9$ ), a suitable amount of reagent 5-Br-PADAP to $40 \mathrm{ml}$ of water in a beaker. This solution was transferred into a separatory funnel and then a suitable amount of the adsorbent naphthalene- $\mathrm{NH}_{4}-\mathrm{TPB}$ was added to it. The separatory funnel was vigorously shaken on a mechanical shaker for $5 \mathrm{~min}$. The solid mass was separated by filtration and manganese was determined from the filtrate by AAS. The solid mass on the filter paper was dried in an oven, kept in a desiccator, and then weighed to determine the mass of the adsorbent. The maximum amount of manganese retained was $6.5 \mathrm{mg} \mathrm{g}^{-1}$ of the adsorbent.
Table 1 Effect of diverse salts and metal ions

\begin{tabular}{lr}
\hline \multicolumn{1}{c}{ Salt or ion } & Tolerance limit \\
\hline $\mathrm{CH}_{3} \mathrm{COONa} \cdot 3 \mathrm{H}_{2} \mathrm{O}, \mathrm{KNO}_{3}$ & $1 \mathrm{~g}$ \\
$\mathrm{~K}_{2} \mathrm{SO}_{4}$ & $400 \mathrm{mg}$ \\
$\mathrm{KI}, \mathrm{NaF}$ & $350 \mathrm{mg}$ \\
Thiourea & $250 \mathrm{mg}$ \\
$\mathrm{NH}_{4} \mathrm{Cl}, \mathrm{Na}_{3} \mathrm{PO}_{4} \cdot 12 \mathrm{H}_{2} \mathrm{O}, \mathrm{K}_{2} \mathrm{CO}_{3}$ & $150 \mathrm{mg}$ \\
$\mathrm{Na}_{2} \mathrm{~S}_{2} \mathrm{O}_{3}$ & $100 \mathrm{mg}$ \\
$\mathrm{Sodium}_{3}$ potassium tartrate & $20 \mathrm{mg}$ \\
$\mathrm{KSCN}$ & $15 \mathrm{mg}$ \\
$\mathrm{Sodium}$ oxalate & $12 \mathrm{mg}$ \\
$\mathrm{Trisodium}$ citrate & $10 \mathrm{mg}$ \\
$\mathrm{Na}{ }_{2} \mathrm{EDTA}$ & $80 \mu \mathrm{g}$ \\
$\mathrm{Mg}(\mathrm{II})$ & $150 \mathrm{mg}$ \\
$\mathrm{Ca}(\mathrm{II})$ & $90 \mathrm{mg}$ \\
$\mathrm{Pb}(\mathrm{II})$ & $10 \mathrm{mg}$ \\
$\mathrm{Cd}(\mathrm{II})$ & $6.0 \mathrm{mg}$ \\
$\mathrm{Sb}(\mathrm{III})$ & $5.0 \mathrm{mg}$ \\
$\mathrm{Ag}(\mathrm{I})$ & $80 \mu \mathrm{g}, 1.5 \mathrm{mg}$ \\
$\mathrm{Cu}(\mathrm{II})$ & $70 \mu \mathrm{g}, 1.0 \mathrm{mg}$ \\
$\mathrm{Ti}(\mathrm{VI})$ & $2.5 \mathrm{mg}$ \\
$\mathrm{Zn}(\mathrm{II}), \mathrm{Ni}(\mathrm{II})$ & $2.0 \mathrm{mg}$ \\
$\mathrm{Cr}(\mathrm{VI}), \mathrm{Cr}(\mathrm{III})$ & $1.5 \mathrm{mg}$ \\
$\mathrm{Se}(\mathrm{VI}), \mathrm{Ga}(\mathrm{III})$ & $1.3 \mathrm{mg}$ \\
$\mathrm{U}(\mathrm{VI})$, & $1.2 \mathrm{mg}$ \\
$\mathrm{Mo}(\mathrm{VI}), \mathrm{Pd}(\mathrm{III}), \mathrm{Te}(\mathrm{IV})$ & $1.0 \mathrm{mg}$ \\
$\mathrm{Fe}(\mathrm{III})$ & $60 \mu \mathrm{g}, 0.9 \mathrm{mg}$ \\
$\mathrm{Os}(\mathrm{VIII})$ & $0.7 \mathrm{mg}$ \\
$\mathrm{Bi}(\mathrm{III}), \mathrm{Fe}(\mathrm{II}), \mathrm{Al}(\mathrm{IIII})$ & $0.6 \mathrm{mg}$ \\
$\mathrm{Rh}(\mathrm{III}), \mathrm{V}(\mathrm{V})$ & $0.5 \mathrm{mg}$ \\
$\mathrm{Co}(\mathrm{II}), \mathrm{Ru}(\mathrm{III}), \mathrm{Hg}(\mathrm{II})$ & $0.4 \mathrm{mg}$ \\
\hline &
\end{tabular}

a. Masked with $3 \mathrm{ml}$ of $1 \% \mathrm{Na}_{2} \mathrm{~S}_{2} \mathrm{O}_{3}$ solution. b. Masked with $3 \mathrm{ml}$ of $5 \% \mathrm{NaF}$ solution.

\section{Calibration and sensitivity}

Since it is possible to retain $0.05 \mu \mathrm{g}$ of manganese from 500 $\mathrm{ml}$ of solution passing through the column, the dissolution with $5.0 \mathrm{ml}$ DMF gives a detection limit of $0.1 \mathrm{ppb}$ for manganese at the minimum instrumental settings. The linearity was maintained in the concentration range of $0.2 \mathrm{ppb}$ to $1.5 \mathrm{ppm}$ manganese in aqueous solution or 0.02 to $3.0 \mathrm{ppm}$ manganese in final DMF solution with a correlation factor of 0.9996. Eight replicate determinations of $5 \mu \mathrm{g}$ of manganese in $5 \mathrm{ml} \mathrm{DMF}$ solution gave a mean absorbance of 0.224 with a relative standard deviation of $1.8 \%$. The sensitivity for $1 \%$ absorption was $19 \mathrm{ppb}$.

\section{Effect of diverse ions}

Various salts and metal ions were added individually to a solution containing $5 \mu \mathrm{g}$ of manganese and the general procedure was applied. The tolerance limit was set as the diverse ion amount required to cause $\pm 3 \%$ error in the determination of manganese. The results obtained are given in Table 1. Among the anions examined, large amounts of chloride, bromide, nitrate, acetate, carbonate and sulfate could be tolerated. Citrate, oxalate, orthophosphate, tartrate and EDTA interfered. Except EDTA, a relatively low amount of these anions could be tolerated. Obviously the stability constants of Mn-EDTA complex must be higher than that of the Mn-5-Br-PADAP complex. Of the metal ions examined, many did not interfere up to $\mathrm{mg}$ levels exceptions were $\mathrm{Fe}(\mathrm{III}), \mathrm{Cu}(\mathrm{II})$ and $\mathrm{Ag}(\mathrm{I}) . \mathrm{Fe}(\mathrm{III})$ was masked with $3 \mathrm{ml}$ of $5 \% \mathrm{NaF}$ solution. $\mathrm{Cu}(\mathrm{II})$ and $\mathrm{Ag}(\mathrm{I})$ were masked with $3 \mathrm{ml}$ of $1 \% \quad \mathrm{Na}_{2} \mathrm{~S}_{2} \mathrm{O}_{3}$ solution. Thus the proposed method is selective and can be 
Table 2 Analysis of manganese in standard alloys

\begin{tabular}{|c|c|c|}
\hline Sample & Composition, $\%$ & Found $^{\mathrm{a}}$ \\
\hline JSS $651-7$ & C, 0.047; Si, 0.072; N, 0.0312; & \multirow[t]{3}{*}{$1.74 \pm 0.06^{b}$} \\
\hline Stainless & $\mathrm{P}, 0.028 ; \mathrm{Cr}, 18.60 ; \mathrm{Al}, 0.002$ & \\
\hline Steel & $\begin{array}{l}\text { S, 0.0063; Mo. 0.84; Co, 0.22; } \\
\text { Mn, 1.72; Ni, 9.20; Cu, 0.082 }\end{array}$ & \\
\hline JSS 653-7 & C, 0.068; Si, 0.63; N, 0.0276; & \multirow[t]{3}{*}{$1.70 \pm 0.04^{c}$} \\
\hline Stainless & $\mathrm{Cr}, 22.53 ; \mathrm{Co}, 0.35 ; \mathrm{Mn}, 1.72 ;$ & \\
\hline Steel & $\mathrm{Ni}, 13.91 ; \mathrm{Cu}, 0.030$ & \\
\hline NKK No. 916 & $\mathrm{Si}, 0.41 ; \mathrm{C}, 0.41 ; \mathrm{Fe}, 0.54$ & \multirow[t]{5}{*}{$0.12 \pm 0.01^{\mathrm{b}}$} \\
\hline Aluminum & $\mathrm{Mg}, 0.10 ; \mathrm{Cr}, 0.05 ; \mathrm{Sn}, 0.05$ & \\
\hline Alloy & $\mathrm{Zn}, 0.30 ; \mathrm{Ti}, 0.10 ; \mathrm{Pb}, 0.04$ & \\
\hline & $\mathrm{Sb}, 0.01 ; \mathrm{B}, 0.0006 ; \mathrm{Zr}, 0.05$ & \\
\hline & $\begin{array}{l}\text { Co, 0.03; Mn, 0.11; Bi, 0.03; } \\
\text { Ni, 0.06; V, 0.02; Cu, 0.27 }\end{array}$ & \\
\hline NKK No. 1021 & $\mathrm{~Pb}, 0.18 ; \mathrm{Zn}, 1.76 ; \mathrm{Si}, 5,56$ & \multirow[t]{6}{*}{$0.19 \pm 0.02^{c}$} \\
\hline $\mathrm{Al}, \mathrm{Si}, \mathrm{Cu}, \mathrm{Zn}$, & Sn, 0.10; Mg, 0.29; Ti, 0.04; & \\
\hline Alloy & $\mathrm{Cr}, 0.03 ; \mathrm{Fe}, 0.99 ; \mathrm{Bi}, 0.01$ & \\
\hline & Zr, 0.01; Sb, 0.01; Ca, 0.004; & \\
\hline & Mn, 0.20; Ni, 0.14; V, 0.007; & \\
\hline & $\mathrm{Cu}, 2.72$ & \\
\hline NKK No. 920 & Cr, 0.27; Si, 0.78; Bi, 0.06; & \multirow[t]{6}{*}{$0.195 \pm 0.008^{b}$} \\
\hline Aluminum & Ti, 0.15; Sn, 0.20; Ga, 0.05; & \\
\hline Alloy & $\mathrm{Pb}, 0.10 ; \mathrm{Fr}, 0.72 ; \mathrm{Zn}, 0.80$ & \\
\hline & $\mathrm{Ca}, 0.03 ; \mathrm{Mg}, 0.46 ; \mathrm{Sb}, 0.10$ & \\
\hline & Co, 0.10; Mn, 0.20; Ni, 0.29; & \\
\hline & $\mathrm{V}, 0.15 ; \mathrm{Cu}, 0.71$ & \\
\hline
\end{tabular}

a. Average of five determinations, standard deviation.

b. Column method was applied.

c. Microcrystalline naphthalene method was applied.

As masking agents, $3 \mathrm{ml}$ of $5 \% \mathrm{NaF}$ solution and $3 \mathrm{ml}$ of $1 \% \mathrm{Na}_{2} \mathrm{~S}_{2} \mathrm{O}_{3}$ solution were added.

used for determination of manganese in standard alloys and biological samples without any prior separation.

Analysis of manganese in standard alloys and steel samples

The proposed method was applied to the determination of manganese in Nippon Keikinzoku Kogyo (NKK) CRM 916, No. 920 Aluminum Alloy, NKK No. 1021, Al, Si, Cu, Zn Alloy, Japanese Standards of Iron and Steel (JSS) CRM 651-7 and 653-7 Stainless Steel. A $0.1 \mathrm{~g}$ sample of the standard aluminum alloy or steel was completely dissolved in $6-14 \mathrm{ml}$ of hydrochloric acid $(1+1)$ by heating on a water-bath and then $1 \mathrm{ml}$ of $30 \%$ ( $\mathrm{v} / \mathrm{v}$ ) hydrogen peroxide was added to it. The excess of peroxide was decomposed by heating the sample on a water-bath. The solution was cooled, filtered if needed, and diluted to $100 \mathrm{ml}$ with distilled water in a standard flask. An aliquot of this sample was taken and the general procedure was applied. The results obtained are given in Table 2. These results are in agreement with the certified values.

\section{Analysis of manganese in biological samples}

The accuracy and applicability of the proposed method has been applied to the determination of manganese in National Institute for Environmental Studies (NIES) No. 1 Pepperbush; NIES, No. 3 Chlorella; NIES, No. 5 Human Hair and NIES, No. 7 Tea Leaves. A $0.1 \mathrm{~g}$ sample was taken in a beaker and dissolved in concentrated nitric acid $(\sim 5 \mathrm{ml})$ with heating. The solution was cooled, diluted and filtered. The filtrate was made to $100 \mathrm{ml}$ with water in a calibrated flask. An aliquot of the sample solution was taken individually and manganese was determined by the general procedure. The results given in Table 3 are in good agreement with the certified values.
Table 3 Analysis of manganese in biological samples

\begin{tabular}{|c|c|c|}
\hline Sample & Composition & Found $^{\mathrm{a}}$ \\
\hline $\begin{array}{l}\text { NIES, No. } 1 \\
\text { Pepperbush }\end{array}$ & $\begin{array}{l}\mathrm{K}, 1.51 \pm 0.06 ; \mathrm{Mn}, 0.203 \pm 0.107 \\
\mathrm{Mg}, 0.408 \pm 0.020 ; \mathrm{Ca}, 1.38 \pm 0.07 \% \\
\mathrm{Cd}, 6.7 \pm 0.5 ; \mathrm{Ni}, 8.7 \pm 0.6 \\
\mathrm{Fe}, 205 \pm 17 ; \mathrm{Co}, 23 \pm 3 ; \\
\mathrm{Pb}, 5.5 \pm 0.8 ; \mathrm{Cu}, 12 \pm 1 ; \\
\mathrm{Zn}, 340 \pm 20 ; \mathrm{Ba}, 165 \pm 10 ; \\
\mathrm{Na}, 106 \pm 13 ; \mathrm{Rb}, 75 \pm 4 ; \\
\mathrm{Sr}, 36 \pm 4 ; \mathrm{As}, 2.3 \pm 0.3 ; \\
\mathrm{P},(1100) ; \mathrm{Cr}(1.3) ; \mathrm{Cs},(1.2) \\
\mathrm{Tl},(0.13) ; \mathrm{Hg},(0.056) \mu \mathrm{g} / \mathrm{g}\end{array}$ & $0.207 \pm 0.008^{b}$ \\
\hline $\begin{array}{l}\text { NIES, No. } 3 \\
\text { Chlorella }\end{array}$ & $\begin{array}{l}\mathrm{K}, 1.24 \pm 0.06 ; \mathrm{Mg}, 0.33 \pm 0.02 \\
\mathrm{Ca}, 0.46 \pm 0.03 ; \mathrm{Fe}, 0.185 \pm 0.010 \\
\mathrm{P}(1.7) \% \\
\mathrm{Zn}, 20.5 \pm 1.0 ; \mathrm{Sr}, 40 \pm 3 \\
\mathrm{Co}, 0.87 \pm 0.05 ; \mathrm{Cd},(0.026) \\
\mathrm{Mn}, 69 \pm 5 ; \mathrm{Pb},(0.60) \\
\mathrm{Cu}, 3.5 \pm 0.3 ; \mathrm{Sc},(0.013) \mu \mathrm{g} / \mathrm{g}\end{array}$ & $68 \pm 1^{c}$ \\
\hline $\begin{array}{l}\text { NIES, No. } 5 \\
\text { Human Hair }\end{array}$ & $\begin{array}{l}\mathrm{Pb}, 6.0 ; \mathrm{Cd}, 0.20 ; \mathrm{K}, 34 ; \mathrm{Rb}, 0.19 \\
\mathrm{Sb}, 0.07 ; \mathrm{Zn}, 169 ; \mathrm{Al}, 240 ; \mathrm{Fe}, 225 \\
\mathrm{Mg}, 208 ; \mathrm{Hg}, 4.4 ; \mathrm{Sc}, 0.05 ; \mathrm{Se}, 1.4 \\
\mathrm{Na}, 26 ; \mathrm{Sr}, 2.3 ; \mathrm{Ti}, 3.2 ; \mathrm{Ca}, 728 \\
\mathrm{Cr}, 1.4 ; \mathrm{Ba}, 2.2 ; \mathrm{Co}, 0.10 ; \mathrm{Mn}, 5.2 \\
\mathrm{Cu}, 16.3 ; \mathrm{Ni}, 1.8 \mu \mathrm{g} / \mathrm{g}\end{array}$ & $5.15 \pm 0.07^{\mathrm{b}}$ \\
\hline $\begin{array}{l}\text { NIES, No. } 7 \\
\text { Tea Leaves }\end{array}$ & $\begin{array}{l}\mathrm{Pb}, 0.80 ; \mathrm{Cd}, 0.030 ; \mathrm{Sb}, 0.014 \\
\mathrm{Zn}, 33 ; \mathrm{Cr}, 0.15 ; \mathrm{Al}, 775 ; \\
\mathrm{Mg}, 1530 ; \mathrm{Ba}, 5.7 ; \mathrm{K}, 18600 \\
\mathrm{Sc}, 0.011 ; \mathrm{Na}, 15.5 ; \mathrm{Sr}, 3.7 \\
\mathrm{Ca}, 3200 ; \mathrm{Cs}, 0.22 ; \mathrm{Co}, 0.12 \\
\mathrm{Mn}, 7.00 ; \mathrm{Ni}, 6.5 ; \mathrm{Cu}, 7.0 \mu \mathrm{g} / \mathrm{g}\end{array}$ & $6.94 \pm 0.08^{c}$ \\
\hline
\end{tabular}

a. Average of five determinations \pm standard deviation. Standard addition method was applied.

b. Column method was applied.

c. Microcrystalline naphthalene method was applied.

As masking agents, $3 \mathrm{ml}$ of $5 \% \mathrm{NaF}$ solution and $3 \mathrm{ml}$ of $1 \% \mathrm{Na}_{2} \mathrm{~S}_{2} \mathrm{O}_{3}$ solution were added.

NIES: National Institute of Environmental Studies reference materials.

NIES, No. 1 \& No. 3 (values in parentheses were approximate and are not certified).

\section{Conclusion}

A solid ion-pair compound produced from $\mathrm{NH}_{4}{ }^{+}$and TPB naphthalene provides a simple and economical method for the preconcentration of manganese from large volumes of alloys and complex samples using 5-Br-PADAP as the complexing agent. This reagent is fairly sensitive and selective for manganese but, with the preconcentration step and the use of atomic absorption spectrometry, its sensitivity and selectivity have been further improved. It is not possible to develop selective methods for metal ions using this adsorbent in spectrophotometry, since many metal-5-Br-PADAP complexes absorb at close wavelengths. However, with the use of AAS this problem can be easily solved.

\section{Acknowledgements}

This reasearch project has been supported by Grant No. NRCI 1719 of National Research Projects and with the Support of National Research Council of Islamic Republic of Iran. 


\section{References}

1. P. L. Malvankar and V. M. Shinde, Analyst, 1991, 116, 1081.

2. S. Marshall, "Toxic Metals-Pollution Control and Worker Protection”, 1976, Noyes Data, NJ, 184 - 189.

3. A. J. Barnard, Jr., Chemist-Analyst, 1955, 44, 104.

4. A. J. Barnard, Jr., Chemist-Analyst, 1958, 47, 46.

5. C. N. Reilly, "Advances in Analytical Chemistry", 1960, Vol. 1, Interscience, New York.

6. M. A. Taher, Anal. Chim. Acta, 1999, 382, 339.

7. Y. M. Quig and L. G. Quin, Talanta, 1983, 30, 265.

8. S. Taguchi, T. Yal, Y. Shimada, and K. Goto, Talanta, 1983, 30, 169.

9. M. Kubota, K. Matsumoto, and K. Terada, Anal. Sci., 1987, 3,45 .

10. Y. Sakai and N. Mori, Talanta, 1986, 33, 161.

11. P. Burba and P. G. Willmer, Talanta, 1983, 30, 381.

12. M. Kimura, H. Yamashita, and J. Komada, Bunseki
Kagaku, 1986, 35, 400.

13. A. S. Khan and A. Chow, Talanta, 1986, 33, 182.

14. A. Wasey, R. K. Bansal, B. K. Puri, and A. L. J. Rao, Talanta, 1984, 31, 205.

15. M. Satake, G. Kano, S. Usami, and B. K. Puri, Indian J. Chem., 1988, 27A, 265.

16. M. A. Taher, B. K. Puri, and R. K. Bansal, Microchem. J. 1998, 58, 21

17. M. A. Taher, S. Puri, M. K. Gupta, and B. K. Puri, Indian J. Chem., 1997, 36A, 913

18. M. A. Taher, A. Mostafavi, B. K. Puri, and S. Puri, Anal Chim. Acta, 1998, 367, 55.

19. M. A. Taher and B. K. Puri, Talanta, 1999, 48, 355.

20. M. A. Taher and B. K. Puri, Analyst, 1995, 120, 1589.

21. M. A. Taher, S. Puri, A. Bhalotra, and B. K. Puri, Quim. Anal. 1999, 18, 181.

22. M. A. Taher, S. Puri, M. K. Gupta, and B. K. Puri, Indian J. Chem. Tech., 1998, 5, 321.

23. A. I. Vogel, "A Text Book of Quantitative Inorganic Analysis", 5th ed., 1989, Longmans, London. 